KONRAD RZEMIENIECKI

Zakład Narodowy im. Ossolińskich we Wrocławiu

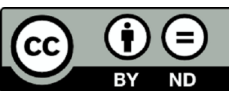

\title{
STRUKTURA I WIELKOŚĆ GOSPODARSTW RODZINNYCH STAROOBRZĘDOWCÓW W POWIECIE ŻYTOMIERSKIM (W GUBERNI WOŁYŃSKIEJ), W KOŃCU XVIII W.
}

Staroobrzędowcy jako grupa wyznaniowa wyodrębnili się na skutek rozłamu Kościoła prawosławnego w Rosji w drugiej połowie XVII w. Konflikt wywołała reforma liturgiczna patriarchy Nikona i związane $\mathrm{z}$ nia poprawianie ksiag religijnych. Inicjatorem reform był car Aleksy Michajłowicz, który planował wprzęgnąc zreformowany Kościół w proces centralizacji państwa rosyjskiego. Równocześnie kościelny nurt reformatorski dążył do ujednolicenia obrzędów religijnych i uporządkowania innych spraw kościelnych, co miało oczyścić liturgię ze zniekształceń i naleciałości powstałych na przestrzeni stuleci, na skutek m.in. kilkuwiekowego ręcznego przepisywania ksiąg liturgicznych, i upodobnić ją do pierwotnej liturgii greckiej. W zamiarze cara reforma miała również służyć scaleniu Kościoła rosyjskiego z podległym patriarsze Konstantynopola Kościołem prawosławnym na lewobrzeżnej Ukrainie, włączonej do państwa moskiewskiego w 1654 r., oraz usunięciu różnic między prawosławnym Kościołem rosyjskim a prawosławnymi Kościołami Wschodu ${ }^{1}$.

Ówczesny zwierzchnik Kościoła prawosławnego, patriarcha Nikon, w lutym $1653 \mathrm{r}$. rozesłał do cerkwi moskiewskich pismo nakazujące liczne zmiany. Między innymi zabronił powszechnie używanego sposobu żegnania się dwoma palcami, wprowadzając w to miejsce sposób trójpalcowy. Wywołało to falę protestów, w tym wyższego duchowieństwa, które reprezentowało pogląd, że jedynie rosyjski Kościół prawosławny

${ }^{1} \dot{Z} y w o t$ protopopa Awwakuma przez niego samego nakreślony i wybór innych pism, tłum., wstęp i kom. W. Jakubowski, Wrocław 1972, s. 11-19; E. Iwaniec, $Z$ dziejów staroobrzędowców na ziemiach polskich, Warszawa 1977, s. 22-24. 
zachował nieskażone obrzędy kościelne ${ }^{2}$. Na soborze zwołanym w 1654 r., w obecności cara, na podstawie starych słowiańskich i greckich rękopisów dokonano poprawek w księgach kościelnych. Pod wprowadzonymi poprawkami złożenia podpisu odmówiła część hierarchów ${ }^{3}$. W 1655 r. kolejny sobór potwierdził uchwały poprzedniego oraz zaakceptował do druku poprawiony mszał. Z kolei sobór z 1656 r. wyłączył z Kościoła wszystkich żegnających się dwoma palcami ${ }^{4}$.

Krytycy zmian byli zsyłani na prowincję, gdzie znajdowali posłuch i uznanie ludu jako obrońcy prawdziwej wiary. Do napięć prowadziła również pospieszna wymiana na nowe starych ksiag liturgicznych, co odbierano jako próby wykorzenienia starej wiary i obrzędów ${ }^{5}$.

Car Aleksy w 1666 r. na zwołanym soborze uznał wschodnie Kościoły za prawosławne, potwierdził uchwały soboru z $1654 \mathrm{r}$. oraz potępił supliki i ich autorów. Do parafii rozesłano specjalne pouczenie dla duchowieństwa zalecające bezwzględne posłuszeństwo władzom kościelnym $^{6}$. Kolejny sobór przypieczętował rozłam. W grudniu 1667 r. odbył się zwołany przez cara sobór grecko-rosyjski z udziałem patriarchów aleksandryjskiego i antiocheńskiego, reprezentujących również pozostałych patriarchów, który zatwierdził uchwały i reformy poprzednich soborów oraz zagroził wyłączeniem z Kościoła tym, którzy by się im sprzeciwiali. Wszyscy, którzy nie godzili się z postanowieniami soboru, w oczach państwa i Kościoła stawali się rozłamowcami (raskolnikami) ${ }^{7}$.

Rozłamowi sprzyjała skomplikowana sytuacja społeczno-ekonomiczna, która spowodowała, że konflikt, wydajacy się dotyczyć niewielkich zmian, przerodził się nie tylko w ruch religijny, ale także w społeczny ruch antyfeudalny, obejmujący wszystkie warstwy społeczne. Prosty lud i niższe duchowieństwo postrzegali prawosławny Wschód inaczej niż kręgi dworskie i hierarchia cerkiewna. Dla prostego ludu wiekowa tradycja miała o wiele większe znaczenie niż głos wschodnich patriarchów, a ruskie obrzędy liturgiczne uznawał za święte. Wszelkie zmiany tradycji liturgicznych uważane były za herezję i wyrzeczenie się jedynej prawdziwej wiary. W odpowiedzi na opór większości społeczeństwa władze odpowiedziały surowymi represjami, które wywołały

${ }^{2} \dot{Z} y w o t$ protopopa Awwakuma..., s. 20; K. Dębiński, Raskot i sekty Prawostawnej Cerkwi Rosyjskiej (Szkic historyczny), Warszawa 1910, s. 19; Z. Jaroszewicz-Pieresławcew, Starowiercy w Polsce i ich ksiegi, Olsztyn 1995, s. 6-7.

${ }^{3}$ E. Iwaniec, dz. cyt., s. 26.

${ }^{4}$ Tamże, s. 27-28.

${ }^{5}$ K. Dębiński, dz. cyt., s. 21; E. Iwaniec, dz. cyt., s. 29.

${ }^{6}$ K. Dębiński, dz. cyt., s. 21; E. Iwaniec, dz. cyt., s. 29.

${ }^{7}$ K. Dębiński, dz. cyt., s. 21-23; E. Iwaniec, dz. cyt., s. 30. 
falę buntów i ruchów chłopskich ogarniających cały kraj . Powszechny terror spowodował masowy exodus staroobrzędowców poza granice Rosji, początkowo do Szwecji, Kurlandii i Rzeczypospolitej, a następnie do innych krajów 9 .

Na tereny Rzeczypospolitej staroobrzędowcy zaczęli napływać już w końcu XVII w. Pierwsza ich osada powstała w dobrach starosty mozyrskiego Karola Kazimierza Chaleckiego, na wyspie Wietka na rzece Soż w powiecie rzeczyckim, i w krótkim czasie stała się prężnym ośrodkiem otoczonym nowo zakładanymi wsiami ${ }^{10}$. Na przełomie lat 20. i 30. XVIII w. w pobliskich dobrach ks. Michała Czartoryskiego, właściciela miasteczka Homel, istniało już wiele osiedli staroobrzędowców, a ich wsie powstawały również w dobrach Lubomirskich, odległych o $50 \mathrm{~km}$ od Homla. Kolejne osiedla staroobrzędowców powstawały w województwie kijowskim. W 1771 r. Jan Mikołaj Chodkiewicz, dziedzic dóbr czarnobylskich, sprowadził ich do Czarnobyla, który na krótko stał się poważnym ośrodkiem tej społeczności. Zasiedlali również wsie na Żytomierszczyźnie, Wołyniu, Podolu oraz w tzw. Inflantach Polskich ${ }^{11}$. Na Żytomierszczyźnie ośrodki staroobrzędowców skupione były na południowy zachód od Żytomierza, w okolicy miasteczka Trojanów. W pierwszej rewizji ludności przeprowadzonej przez Rosjan na ziemiach dawnej Rzeczypospolitej w 1795 r., tzw. piatej rewizji, odnotowano pięć różnej wielkości kolonii staroobrzędowców. Były to wsie Horodyszcze z 14 staroobrzędowcami, Żeleźniaki z 163, Koszarka z 110, Pilipy z 147 i Słobodyszcza z 36. W sumie 470 osób. Nie były to nowe wsie, lecz wsie już istniejące, w których staroobrzędowcy tworzyli swoje kolonie. Nie sposób z całą pewnością stwierdzić, czy wyżej wymienione wsie to wszystkie osady powiatu żytomierskiego zamieszkałe wówczas przez tę społeczność. W kolejnych rewizjach staroobrzędowcy widoczni są również w Berdyczowie, Niechworoszczy, Żytomierzu, Korowincach, Podolancach oraz w Wilszance, Henrykówce i Jahodence. Najprawdopodobniej powyższa lista wyczerpuje wykaz miejscowości zasiedlonych przez staroobrzędowców w powiecie żytomierskim w końcu XVIII i pierwszej połowie XIX w.

Podstawą poniższych badań jest pięć wymienionych wcześniej rosyjskich spisów ludności, przeprowadzonych w ramach tzw. piątej rewizji, której formularze spisowe są obecnie przechowywane w Państwowym

\footnotetext{
${ }^{8}$ K. Dębiński, dz. cyt., s. 26-27; E. Iwaniec, dz. cyt., s. 22.

${ }^{9}$ E. Iwaniec, dz. cyt., s. 33; Z. Jaroszewicz-Pieresławcew, dz. cyt., s. 8-9.

${ }^{10}$ E. Iwaniec, dz. cyt., s. 52-53; Z. Jaroszewicz-Pieresławcew, dz. cyt., s. 13, 15.

${ }^{11}$ E. Iwaniec, dz. cyt., s. 54, 60-69; Z. Jaroszewicz-Pieresławcew, dz. cyt., s. 15.
} 
Archiwum Obwodu Żytomierskiego w Żytomierzu ${ }^{12}$. Ukaz zapowiadajacy przeprowadzenie rewizji został opublikowany 23 VI 1794 r., a urzędowy formularz spisowy wydrukowany i rozesłany do niższych urzędów w celu sprzedaży zainteresowanym. Władze nie były rygorystyczne w tej sprawie i przyjmowano do urzędów również spisy sporządzone własnoręcznie, jeśli graficznie odpowiadały zatwierdzonemu wzorowi. Dla przyłączonych do Rosji ziemiach dawnej Rzeczypospolitej przygotowano formularz dwujęzyczny - po polsku i rosyjsku. Według Jurija Lehuna i Oleksandra Pietrienki stosowanie języka polskiego jako urzędowego na terenach ziem Rzeczypospolitej sprawiło, że polska część piątej rewizji wyróżnia się większym uporządkowaniem i ujednoliceniem $\mathrm{w}$ pisowni imion i nazw miejscowości ${ }^{13}$.

Staroobrzędowcy $\mathrm{w}$ powiecie żytomierskim ${ }^{14} \mathrm{w}$ większości zostali spisani jesienią 1795 r. Wyjątek stanowią kupcy we wsi Żeleźniak, których spisano już w czerwcu, a mieszkających w tej samej wsi staroobrzędowców utrzymujących się z pracy na roli spisano oddzielnie dopiero we wrześniu. Z nagłówków spisów i podpisów pod nimi wynika, że wszystkie spisy sporządzili starsi tych społeczności. Nie wiadomo, jak i czy władze przeprowadziły ich weryfikację. Spisy w wersji polskiej i rosyjskiej składaja się ze strony tytułowej, na której zapisano, jakiej kategorii ludności dotyczy spis i z jakiej miejscowości oraz stron spisowych, z których pierwsza rozpoczynała się nagłówkiem zawierającym informacje o dacie sporządzenia spisu, nazwie miejscowości, powiecie i guberni, w której leżała, o właścicielu lub posesorze oraz o tym, kto sporządził spis. Część spisowa składała się z czterech kolumn, z których w pierwszej zapisywano imiona, nazwiska, nazwiska odojcowskie głów rodzin i relację wobec głowy rodziny, w drugiej i trzeciej - osobno wiek mężczyzn i kobiet, czwartą przeznaczono na uwagi, zapisując w niej głównie informacje o zajęciu głowy rodziny. Znajduja się tam także informacje o tym, czy chodzi o ludność osiadła, czy o nieosiadła. Obie te kategorie ludności spisano oddzielenie, mimo że najczęściej zamieszkiwali oni te same domy. Najczęściej nie zaznaczano przy tym, w czyim domu mieszkali nieosiedli. Taki sposób rejestracji ludności

12 Державний архів Житомирської області, f. 118, dz. 14, rkps 337, k. 313-359.

${ }^{13}$ Ю. Легун, О. Петренко, Ревізійний перепис населення 1795 р. Браилавська губерніл, ч. 1: Бершадський повіт, t. 1: Ревізійні списки селян сіл: Крикливець, Крушинівка, Лугувате, Любашівка, Ободівка,Поташня, П'ятківка, Рогізка, Татарівка, Христище, Яланець, Вінниця 2003, s. 8-12.

${ }^{14}$ Wedle wprowadzonego po zaborach rosyjskiego podziału administracyjnego badany obszar leżał w powiecie żytomierskim guberni wołyńskiej, która do połowy 1795 r. nosiła nazwę izasławskiej (zasławskiej). 
niestety właściwie uniemożliwia badanie struktury gospodarstw. Za ludność nieosiadłą uznawano służbę i komorników, określając ich zajęcie zapisem: „prostą robotą bawią się” lub „zarabiają u różnych mieszkańców”. W wypadku staroobrzędowców nie można stwierdzić, czy ludność ta mieszkała tylko w domach osiadłych staroobrzędowców, czy też w domach miejscowej ludności greckokatolickiej.

Tabela 1. Skupienie wieku w spisach staroobrzędowców (powyżej 17 lat) w powiecie żytomierskim w 1795 r. (\%)

\begin{tabular}{c|c|c}
\hline Cyfra skupienia wieku & Kobiety & Mężczyźni \\
\hline 0 & 60,4 & 57,2 \\
\hline 1 & 0,9 & 1,2 \\
\hline 2 & 0,9 & 1,9 \\
\hline 3 & 3,6 & 2,5 \\
\hline 4 & 3,6 & 0,6 \\
\hline 5 & 16,2 & 25,3 \\
\hline 6 & 1,8 & 1,2 \\
\hline 7 & 2,7 & 0,6 \\
\hline 8 & 9,9 & 8,3 \\
\hline 9 & - & 1,2 \\
\hline liczby bezwzględne & 111 & 159 \\
\hline
\end{tabular}

Źródło: Державний архів Житомирської області, f. 118, dz. 14, rkps 337, k. 313-359.

Analizowane spisy charakteryzuje typowe dla osiemnastowiecznych dokumentów tego rodzaju skupienie wieku na cyfrze „0” i w mniejszym stopniu na cyfrze „5” (zob. tab. 1), co świadczy o szacunkowej wiedzy o swoim wieku ówczesnej ludności oraz o przeprowadzeniu spisów tylko w oparciu o wiedzę spisywanego. Skupienie wieku na cyfrze „0” częściej widoczne było wśród ludności w bardziej zaawansowanym wieku.

Dla oceny jakości spisu ważniejsza jest struktura wieku i płci spisanej w nim ludności. Przyjmuje się, że spis pochodzący z tego okresu można uznać za dokument wysokiej jakości, jeżeli odsetek ludności do 14. roku życia zbliża się do $40 \%$, rocznik „,0” wynosi ponad $4 \%$, rocznik „1” ponad 3,5\%, a oba łącznie około 8\%. Roczniki powyżej 64. roku życia nie powinny przekraczać $3-3,4 \%{ }^{15}$. W wypadku spisów społeczności

${ }^{15}$ I. Gieysztorowa, Wstep do demografii staropolskiej, Warszaw 1976, s. 100, 101, 132, 133; C. Kuklo, Kobieta samotna w społeczeństwie miejskim u schytku Rzeczypospolitej szlacheckiej. Studium demograficzno-społeczne, Białystok 1998, s. 48. 
staroobrzędowców największym problemem w ich ocenie jest skromna statystycznie podstawa analizy, co przy niewielkich zmianach ilościowych prowadzi do istotnych zmian odsetka ludności w poszczególnych grupach wiekowych. Mimo tego zastrzeżenia o spisach tych można powiedzieć, że charakteryzuja je elementy powszechnie stwierdzane $\mathrm{w}$ innych spisach osiemnastowiecznych. Maja one poprawny odsetek ludności do 14. roku życia, widać w nich pomijanie dzieci, które nie ukończyły pierwszego roku życia oraz pomijanie lub zapisywanie jako starsze dzieci rocznych. Widoczne sa również braki w populacji kobiet między 25. a 34. rokiem życia, co tłumaczy się wysoką śmiertelnością okołopołogową, a także widoczny wysoki odsetek osób starych, zwłaszcza mężczyzn (zob. tab. 2).

Tabela 2. Struktura wieku staroobrzędowców w powiecie żytomierskim w 1795 r. (\%)

\begin{tabular}{l|c|c|c}
\hline Przedział wieku & Kobiety & Mężczyźni & Razem \\
\hline $\mathbf{0}$ & $\mathbf{2 , 0}$ & $\mathbf{1 , 5}$ & $\mathbf{1 , 7}$ \\
\hline $\mathbf{1}$ & $\mathbf{1 , 0}$ & $\mathbf{2 , 6}$ & $\mathbf{1 , 9}$ \\
\hline $0-4$ & 12,7 & 11,3 & 11,9 \\
\hline $5-14$ & 27,3 & 21,9 & 24,3 \\
\hline $\mathbf{0}-\mathbf{1 4}$ & $\mathbf{4 0 , 0}$ & $\mathbf{3 3 , 2}$ & $\mathbf{3 6 , 2}$ \\
\hline $\mathbf{1 5 - 2 4}$ & 20,0 & 17,8 & 18,7 \\
\hline $25-34$ & 11,7 & 18,1 & 15,3 \\
\hline $35-44$ & 10,2 & 9,8 & 10,0 \\
\hline $45-54$ & 5,9 & 5,7 & 5,7 \\
\hline $55-64$ & 7,3 & 4,5 & 5,7 \\
\hline powyżej 65 & 4,4 & 10,9 & 8,2 \\
\hline b.d. & 0,5 & - & 0,2 \\
\hline liczby bezwzględne & 205 & 265 & 470 \\
\hline
\end{tabular}

Źródło: Державний архів Житомирської області, f. 118, dz. 14, rkps 337, k. 313-359.

Na strukturę wieku, rodziny i liczbę ludności wpływało również to, że osadnictwo staroobrzędowców w tych wsiach miało krótka, nie dłuższą niż kilkunastoletnia, metrykę. Bardzo możliwe, że byli to osadnicy opuszczający Czarnobyl po śmierci Jana Mikołaja Chodkiewicza w 1781 r. i konflikcie z jego spadkobiercami ${ }^{16}$. Nieco światła o ich pochodzeniu, ale nie o dacie przybycia, rzucają informacje zawarte w samych spisach. Przy 34 osobach (26 gospodarzach i 8 osobach nieosiadłych)

\footnotetext{
${ }^{16}$ E. Iwaniec, dz. cyt., s. 54, 60.
} 
zaznaczono informację o miejscu, z którego przybyli na Żytomierszczyznę. Przy jednej osobie zaznaczono, że pochodzi z Czarnobyla, przy dziesięciu, że urodzili się w Polsce, ale bez sprecyzowania, o jaki konkretnie obszar chodzi. Prawdopodobnie chodziło o dawną Koronę, ponieważ przy kolejnych dziesięciu zaznaczono, że pochodzą z Białorusi, w tym jeden z Połocka, a siedmiu z Witebska. Przy dziewięciu zapisano, że pochodzą z Rosji, ale tylko przy trzech podano informację, że ich ojciec przybył w Wielkich Łuk, a przy jednym, że z Antonowego Monastyru. Jeden staroobrzędowiec pochodził z Inflant, a trzech z miejscowości o nieznanej lokalizacji (Podboszajkowice, Dworcowa Wołość, Równa Swoboda). Jak widać z powyższego zestawienia, poszczególni członkowie badanej społeczności pochodzili z bardzo różnych i odległych od siebie miejscowości, a także niewątpliwie reprezentowali różne tradycje i zwyczaje życia codziennego i wyznawanej religii. Najprawdopodobniej były to wspólnoty $\mathrm{w}$ fazie formowania i wypracowywania swoich wewnętrznych zwyczajów.

Niewielka podstawa statystyczna jest tu znacznym problemem, uniemożliwiającym szerszą analizę, ale warto ją podjąć przynajmniej z dwóch względów. Po pierwsze, jest to społeczność mała i w odróżnieniu od ludności rzymskokatolickiej czy greckokatolickiej nie można znaleźć lepszych i obszerniejszych statystycznie spisów. Po drugie, jest to społeczność, która na tym obszarze i w tym okresie nie była dotąd badana. Jedyne prace związane ze staroobrzędowcami w Rzeczypospolitej dotyczą społeczności zamieszkującej okolice Białegostoku oraz Mazury i dotyczą głównie kultury i języka. Sa to badania Eugeniusza Iwańca i Irydy Grek-Pabisiowej ${ }^{17}$. Liczne badania nad staroobrzędowcami sa prowadzone w Rosji i na Ukrainie. Badania ukraińskie dotyczą głównie Hetmańszczyzny, gdzie staroobrzędowcy osiedlali się od końca XVII w. i skąd później emigrowali do Rzeczypospolitej. Jako jednego z ważniejszych ukraińskich badaczy tego tematu należy wymienić Jurija Wołoszyna ${ }^{18}$.

Z liczby 470 staroobrzędowców ujętych w spisach 415 osób zostało określonych jako ludność osiadła i spisanych w 64 gospodarstwach, a 55 jako ludność nieosiadła. Jak zaznaczono wcześniej, ze spisów nie wynika, czy ludność nieosiadła mieszkała tylko w gospodarstwach osiadłych

${ }^{17}$ E. Iwaniec, dz. cyt.; I. Grek-Pabisiowa, Staroobrzędowcy. Szkice z historii, języka, obyczajów. Wybór prac z okazji 45-lecia pracy naukowej, Warszawa 1999 (tam dalsza literatura).

${ }^{18}$ Ю.В. Волошин, Розкольницькі слободи на території Північної Гетьланшини y XVIII cm. (історико делографічний аспект), Полтава 2005 (w książce autor bada zagadnienia demograficzne i strukturę rodziny; tam obszerna literatura ukraińska i rosyjska). 
współwyznawców, czy również częściowo w gospodarstwach miejscowej ludności greckokatolickiej. Jeśli przyjąć drugą opcję, to należy równocześnie założyć, że w gospodarstwach staroobrzędowców mogła zamieszkiwać służba i komornicy obrządku unickiego. Przyjmując zatem, że 470 osób odpowiada rzeczywistej liczbie mieszkańców gospodarstw staroobrzędowców, otrzymujemy średnie zaludnienie na poziomie około 7,3 osoby na gospodarstwo. Natomiast rodzina własna gospodarzy liczyła przeciętnie 6,5 osoby.

$\mathrm{Na}$ czele gospodarstw i równocześnie rodzin ${ }^{19}$ stali niemal wyłącznie żonaci mężczyźni (52) lub wdowcy (9). Wyjątkiem były owdowiałe kobiety (3), które pełniły funkcję gospodarza zapewne czasowo, do czasu powtórnego małżeństwa lub osiagnięcia wieku dorosłego przez dzieci. Wśród gospodarzy nie było kawalerów i osób poniżej 25. roku życia.

Tabela 3. Wielkość i struktura rodziny staroobrzędowców w powiecie żytomierskim w 1795 r.

\begin{tabular}{l|c|c|c|c|c}
\hline $\begin{array}{c}\text { Wiek głowy } \\
\text { rodziny }\end{array}$ & $\begin{array}{c}\text { Liczba } \\
\text { rodzin }\end{array}$ & $\begin{array}{c}\text { Głowa rodziny } \\
\mathbf{z} \text { żoną }\end{array}$ & Dzieci & Krewni & $\begin{array}{c}\text { Wielkość } \\
\text { rodziny }\end{array}$ \\
\hline $25-34$ & 8 & 1,9 & 1,8 & 1,9 & 5,5 \\
\hline $35-44$ & 10 & 1,8 & 2,4 & 0,7 & 4,9 \\
\hline $45-54$ & 13 & 1,8 & 3,8 & 0,2 & 5,8 \\
\hline $55-64$ & 11 & 1,8 & 3,9 & 1,1 & 6,8 \\
\hline powyżej 65 & 22 & 1,8 & 2,7 & 3,3 & 7,8 \\
\hline Razem & 64 & 1,8 & 3,0 & 1,7 & 6,5 \\
\hline
\end{tabular}

Źródło: Державний архів Житомирської області, f. 118, dz. 14, rkps 337, k. 313-359.

Wielkość rodziny nie była wartością stałą i podlegała ciagłym zmianom wraz cyklem życia członków rodziny. W wypadku staroobrzędowców przeciętna rodzina liczyła 6,5 osoby (zob. tab. 3), a jej struktura i wielkość zmieniała się z czasem, przyjmując tendencję wzrostową wraz z wiekiem głowy rodziny i osiagając najwyższą wartość przy najstarszych z nich, liczyła wówczas średnio 7,8 osoby. Zmieniała się również ich struktura wewnętrzna. W strukturze rodzin najmłodszych gospodarzy istotna częścią składową byli krewni jego lub jego żony, których liczba przewyższała nawet liczbę własnych dzieci. Ich obecność w rodzinie, ale i w gospodarstwie, wraz z wzrostem wieku głowy rodziny i przy rosnącej liczbie jego dzieci stopniowo się zmniejszała, osiagając najniższą wartość około 50. roku życia głowy rodziny. W tym

\footnotetext{
${ }^{19}$ Pojęcia te będą dalej stosowane zamiennie.
} 
okresie większość rodzin stawała się nuklearnymi, czyli była złożona tylko z rodziców i dzieci. Po przekroczeniu tego punktu udział krewnych w strukturze rodziny ponownie wzrastał, ale zmieniał się ich charakter. W gospodarstwach najmłodszych głów rodzin (do 34. roku życia) krewni to przede wszystkim owdowiałe matki i rzadziej teściowe oraz nieletnie rodzeństwo gospodarza, z wyjątkową obecnością rodzeństwa jego żony (zob. tab. 4). Obecność rodzeństwa żony w gospodarstwie zapewne dotyczyła tylko sytuacji, w których obecny gospodarz był zięciem, a nie synem poprzedniego gospodarza i po jego śmierci odziedziczył gospodarstwo. W nielicznych gospodarstwach zamieszkiwali bracia z żonami. Następnie u coraz starszych gospodarzy liczba krewnych sukcesywnie spadała (krewni ze starszego pokolenia wymieraja, a krewni z pokolenia gospodarzy zakładają rodziny i w większości opuszczaja gospodarstwo brata), by między 45. a 54. rokiem życia gospodarza osiagnąć stan, w którym większość gospodarstw składała się wyłącznie $\mathrm{z}$ rodziny nuklearnej gospodarza, a tylko w nielicznych mieszkali również krewni (zob. tab. 4). W gospodarstwach gospodarzy powyżej 54. roku życia ponownie widoczni sa krewni, ale o innej strukturze. W większości wypadków były to dorosłe dzieci gospodarza ze współmałżonkami i swoimi dziećmi - najczęściej synowie z rodzinami, dużo rzadziej córki. Poza rodzinami dzieci gospodarza w gospodarstwach najstarszych gospodarzy w miarę często można było spotkać również dorosłe rodzeństwo gospodarzy z własnymi rodzinami (zob. tab. 4).

Tabela 4. Struktura krewnych w zależności od wieku gospodarza wśród staroobrzędowców w powiecie żytomierskim w 1795 r.

\begin{tabular}{|c|c|c|c|c|c|c|c|c|c|c|c|c|}
\hline \multirow{3}{*}{ 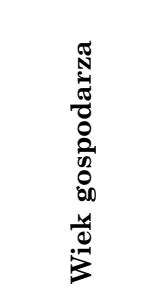 } & \multicolumn{12}{|c|}{ Krewni } \\
\hline & \multicolumn{2}{|c|}{ wstępni } & \multicolumn{6}{|c|}{ zstępni } & \multicolumn{3}{|c|}{ boczni } & \multirow[b]{2}{*}{$\ddot{\Xi}$} \\
\hline & $\frac{\mathscr{d}}{\frac{d}{0}}$ & 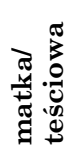 & 空 & 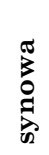 & 苋. & 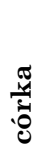 & 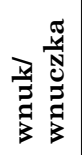 & 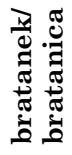 & $\begin{array}{l}\vec{\pi} \\
\overrightarrow{0}\end{array}$ & 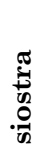 & 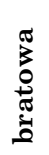 & \\
\hline $25-34$ & - & 5 & - & - & - & - & - & - & 6 & 3 & 2 & - \\
\hline $35-44$ & - & 2 & - & - & - & - & - & - & 4 & 1 & - & - \\
\hline $45-54$ & - & - & - & - & - & - & - & - & 2 & - & 1 & - \\
\hline $55-64$ & - & - & 4 & 4 & - & - & 3 & - & - & - & - & 1 \\
\hline powyżej 65 & - & - & 15 & 15 & 2 & 2 & 23 & 9 & 4 & - & 4 & 2 \\
\hline Razem & - & 7 & 19 & 19 & 2 & 2 & 26 & 9 & 16 & 4 & 7 & 3 \\
\hline
\end{tabular}

Źródło: Державний архів Житомирської області, f. 118, dz. 14, rkps 337, k. 313-359 
Rodziny staroobrzędowców najczęściej składały się z dwóch pokoleń (50), zazwyczaj była to para małżeńska i dzieci, rzadziej z trzech (13) lub jednego pokolenia (1). Rodziny trzypokoleniowe zdecydowanie przeważały w najstarszej grupie wiekowej głów rodzin, najczęściej były to rodziny osób powyżej 64. roku życia (10). Wielopokoleniowość rodziny związana była również z jej statusem ekonomicznym. Osoby stojące na czele 7 z 13 rodzin trzypokoleniowych zostały określone w spisie jako zajmujace się handlem. Wszyscy mieszkali we wsi Żeleźniak.

Bardziej szczegółową analizę rodziny, dzięki rozbudowanej klasyfikacji pokrewieństwa, umożliwia zaproponowana przez Petera Lasletta typologia struktury rodziny ${ }^{20}$. Ze względu na mała podstawę analityczna ten rozbudowany system przedstawię tutaj w formie uproszczonej. W typologii Lasletta istnieje pięć podstawowych kategorii, z których każda zawiera kilka szczegółowych typów: typ I - osoby samotne (wdowy, wdowcy, osoby w stanie bezżennym lub o nieokreślonym stanie cywilnym), typ II - gospodarstwa nierodzinne (gospodarstwa rodzeństwa, mieszkających razem dalszych krewnych spoza rodziny nuklearnej oraz wspólne gospodarstwa osób niespokrewnionych), typ III - rodziny z jedną komórką małżeńska (małżeństwo bezdzietne i z dziećmi, wdowcy i wdowy z dziećmi), typ IV - rodziny rozszerzone (o krewnych głowy rodziny), typ $\mathrm{V}$ - rodziny złożone z co najmniej dwóch lub więcej małżeństw (małżeństwo głowy rodziny i para małżeńska z generacji starszej, młodszej bądź tej samej lub kilka par małżeńskich różnych generacji ${ }^{21}$.

Struktura rodzin staroobrzędowców na Żytomierszczyźnie charakteryzowała się przewaga rodzin o strukturze nuklearnej $(57,8 \%)$ nad rodzinami o bardziej skomplikowanej strukturze: rozszerzonymi $(18,8 \%)$ i złożonymi (23,4\%) (zob. tab. 5). Na równie wysoki odsetek rodzin nuklearnych również wśród greckokatolickiej ludności chłopskiej tego samego obszaru wskazują dane przedstawione przez Mykołę Krykuna dla Żytomierszczyzny w oparciu o spisy miejscowej komisji cywilno-wojskowej z $1791 \mathrm{r}$. W ich świetle rodziny nuklearne stanowiły $55,4 \%$, rozszerzone $8,2 \%$, a złożone $34,4 \%^{22}$. Podobny odsetek rodzin nuklearnych stwierdzono np. w Połtawie, gdzie wśród miejscowej ludności kozackiej stanowiły one 59\%, a rodziny rozszerzone i złożone

${ }^{20}$ P. Laslett, Introduction. The History of the Family w: Household and Family in Past Time, Cambridge 1972, s. 28-32.

${ }^{21}$ Tamże.

${ }^{22}$ М. Крикун, Населення дологосподарств у Житолирськолу повіті Київського воєводства 1791 року, w: tenże, Воєводства Правобережної України у XVI-XVIII століттлх. Статті і матеріали, Львів 2012, s. 569. 
odpowiednio 11,9 i $26,7 \%^{23}$, na obszarach wiejskich Hetmańszczyny zaś udział rodzin nuklearnych w strukturze rodzin staroobrzędowców był niższy i wynosił $47,1 \%$, przy $39,4 \%$ rodzin złożonych i $9,6 \%$ rozszerzonych ${ }^{24}$. W obu wypadkach dane pochodza z 1767 r., ze spisu przeprowadzonego przez generał-gubernatora Małorosji Piotra Rumiancewa. W tym samym okresie na Starodubowszczyźnie wśród ludności ukraiń skiej proporcje te wyglądały jeszcze inaczej: rodziny nuklearne $-34,8 \%$, rozszerzone $-4,2 \%$, złożone $-60,9 \%{ }^{25}$.

$\mathrm{Z}$ danych przedstawionych $\mathrm{w}$ tabeli 5 można wyciagnąc podobne wnioski jak przy analizie struktury krewnych. Rodzina i gospodarstwo pod wpływem czynników demograficznych ulegały ciagłym zmianom, na które gospodarz musiał reagować w zależności od sytuacji ekonomicznej, w jakiej znajdowało się gospodarstwo. Należało zadbać o odpowiednią siłę robocza w gospodarstwie, niezbędną do pracy we własnym gospodarstwie i dla odrobienia pańszczyzny. Gospodarstwa najmłodszych gospodarzy najczęściej były nuklearnymi, ewentualnie rozszerzonymi i bardzo rzadko złożonymi, a na ich strukturę składały się owdowiałe matki, nieletnie rodzeństwo i rzadko rodzeństwo (bracia) z rodzinami. W wypadku rodzin staroobrzędowców próba jest niewielka, ale na szerokim materiale statystycznym prawdopodobnie będzie można stwierdzić dla tego terytorium wśród gospodarstw do około 34. roku życia gospodarza przewage gospodarstw rozszerzonych. W kolejnych grupach wiekowych gospodarzy następowało uproszczenie form rodzinnych i stopniowy wzrost odsetka rodzin nuklearnych, z najwyższym udziałem w ogóle gospodarstw przypadajacym na okres mniej więcej między 45. a 54. rokiem życia głowy rodziny. W gospodarstwach starszych gospodarzy, zwłaszcza powyżej 64 . roku życia, przeważaja rodziny złożone i rozszerzone, w których, oprócz małżeństwa gospodarza, licznie mieszkali jego dorosłe dzieci z rodzinami. W odróżnieniu od ziem etnicznie polskich, gdzie rodziny złożone składały się głównie z dwóch par małżeńskich: gospodarzy i ich dorosłego dziecka z rodzina, wśród staroobrzędowców, ale zapewne i wśród ogółu miejscowej ludności, bardzo często składały się z trzech par małżeńskich. Przykładowo na dziesięć rodzin złożonych w grupie głów rodzin powyżej 65. roku życia aż w siedmiu domostwach mieszkały po trzy pary

${ }^{23}$ Ю.В. Волошин, Родина й дологосподарство козаків ліста Полтави в другій половині XVIII cm. (за матеріалали Румяниевського опису), w: Полтавські історичні студї: ювілейний збірник на пошану Віктора Ревегука, Полтава 2013, s. 77.

${ }_{24}$ Tenże, Розкольницькі слободи..., s. 226.

25 Tamże, s. 228. 
małżeńskie. W sześciu było to małżeństwo głowy rodziny i po dwa małżeństwa jego dzieci, w siódmym obok małżeństwa głowy rodziny małżeństwo jego syna i brata.

Tabela 5. Struktura gospodarstw domowych według typologii Petera Lasletta wśród staroobrzędowców w powiecie żytomierskim w 1795 r.

\begin{tabular}{l|c|c|c|r|r|r}
\hline Wiek gospodarza & Razem & I & II & III & IV & V \\
\hline $25-34$ & 8 & - & - & 4 & 3 & 1 \\
\hline $35-44$ & 10 & - & - & 8 & 2 & - \\
\hline $45-54$ & 13 & - & - & 12 & - & 1 \\
\hline $55-64$ & 11 & - & - & 7 & 1 & 3 \\
\hline powyżej 65 & 22 & - & - & 6 & 6 & 10 \\
\hline liczby bezwzględne & 64 & - & - & 37 & 12 & 15 \\
\hline$\%$ & 100 & - & - & 57,8 & 18,8 & 23,4 \\
\hline
\end{tabular}

Źródło: Державний архів Житомирської області, f. 118, dz. 14, rkps 337, k. 313-359.

Mimo że materiał, jakim dysponujemy dla staroobrzędowców z Żytomierszczyzny jest ograniczony, to pozwala określić pewne ogólniejsze charakterystyki badanej społeczności co do wielkości oraz struktury rodziny i gospodarstwa. Przeciętna rodzina tej społeczności liczyła 6,5 osoby, a gospodarstwo prawdopodobnie około 7,3 mieszkańców. Rodzina staroobrzędowców stanowiła rozbudowaną strukturę krewniaczą i często, najczęściej w gospodarstwach prowadzonych przez najstarszych gospodarzy, składała się z trzech par małżeńskich z dziećmi. Nie były to skomplikowane struktury. Składały się głównie z najbliższej rodziny gospodarza w postaci rodzeństwa nieletniego i z własnymi rodzinami, dorosłych dzieci z rodzinami oraz rodziców. Do wyjątkowych należały sytuacje, gdy w gospodarstwie mieszkała np. bratanica głowy rodziny z dzieckiem. Stopień skomplikowania struktury rodzinnej najczęściej związany był z wiekiem głowy rodziny. Najliczniej występowały one gospodarstwach najmłodszych i najstarszych gospodarzy. Rodziny osób w średnim wieku najczęściej miały nuklearny charakter.

Należy również podkreślić patriarchalny charakter pozostawania i obecności dorosłych krewnych w gospodarstwach. W wypadku rodzeństwa w gospodarstwach pozostawali wyłącznie żonaci bracia gospodarza, rzadko też występuje nieletnie rodzeństwo żony gospodarza. Dorosłe dzieci z rodzinami w gospodarstwie rodziców to przede wszystkim synowie. Obecność w gospodarstwie zamężnej córki i zięcia nie była może zjawiskiem wyjątkowym, ale nie była też częsta. Zatem dziedziczenie zdecydowanej większości gospodarstw odbywało się w linii 
męskiej. Stąd też rzadkość w gospodarstwach nieletniego rodzeństwa i starych rodziców żony gospodarza.

\section{Bibliografia}

Żywot protopopa Awwakuma przez niego samego nakreślony $i$ wybór innych pism, tłum., wstęp i kom. W. Jakubowski, Wrocław 1972.

Gieysztorowa I., Wstep do demografii staropolskiej, Warszaw 1976.

Grek-Pabisiowa I., Staroobrzędowcy. Szkice z historii, języka, obyczajów. Wybór prac $z$ okazji 45-lecia pracy naukowej, Warszawa 1999.

Iwaniec E., $Z$ dziejów staroobrzędowców na ziemiach polskich, Warszawa 1977.

Jaroszewicz-Pieresławcew Z., Starowiercy w Polsce i ich księgi, Olsztyn 1995. Kuklo C., Kobieta samotna w spoteczeństwie miejskim u schytku Rzeczypospolitej szlacheckiej. Studium demograficzno-społeczne, Białystok 1998.

Волошин Ю.В., Розкольницькі слободи на території Північної Гетьланшини у XVIII cm. (історико делографбічний аспект), Полтава 2005.

Волошин Ю.В., Родина й домогосподарство козаків міста Полтави в другій половині XVIII cm. (за матеріалали Румлнцевського опису) w: Полтавські історичні студії: ювілейний збірник на пошану Віктора Ревегука, Полтава 2013.

Крикун М., Населення домогосподарств у Житомирському повіті Київського воєводства 1791 року, w: tenże, Воєводства Правобережної Украйни у XVI-XVIII століттях. Статті і матеріали, Львів 2012.

Konrad Rzemieniecki

On the Old Believers in Ukraine in the eighteenth century (Summary)

The article offers the analysis of the structure and size of the households of the Old Believers living in the vicinity of Żytomierz in Ukraine in the eighteenth century. The Old Believers form a denomination that carved itself off from the Russian Orthodox Church in the latter half of the seventeenth century. The population census of 1795 serves as the basis of the analysis carried out in the paper. The households of the Old Believers were usually made up of 7.3 persons, with 6.5 persons forming the host's own family. The majority of the families of the Old Believers were nuclear in their structure. Worthy of note is also a patriarchal character of the presence of adult relatives in these households. Among the host's adult relatives who stayed in his household were, in the main, either his married brothers or his married sons. 
The vast majority of the farms owned by the Old Believers were thus inherited by male successors.

Key words: The Old Believers, Kievan province, eighteenth century, the Wołyń province 